DOI: $10.19195 / 0137-1134.115 .11$

\author{
RAFAŁ MIKOWSKI \\ ORCID: 0000-0002-9465-8510 \\ Uniwersytet Wrocławski
}

\title{
KILKA UWAG O PODSTAWACH PRAWNYCH OGRANICZEŃ DOSTĘPU DO BRONI PALNEJ W POLSCE
}

\begin{abstract}
Abstrakt: W opracowaniu przedstawione zostały podstawy prawne dostępu do broni palnej w Polsce $\mathrm{w}$ zarysie przy uwzględnieniu aktualnych tendencji związanych z obowiązkiem państwa zapewnienia obywatelom bezpieczeństwa. Analiza zasad konstytucyjnych i obowiązującego ustawodawstwa przy uwzględnieniu regulacji rozporządzeniowych prowadzi do wyjaśnienia znaczenia ograniczeń wprowadzanych na tym polu przez ustawodawcę. Prewencyjne i zachowawcze podejście ustawodawcy do oczekiwań niektórych zainteresowanych środowisk uzasadnia twierdzenie, że dopuszczenie do obrotu broni palnej stanowi restrykcyjnie regulowany wyjątek od zasady ograniczania dostępu do broni palnej, co wymiernie przekłada się na zwiększenie poczucia bezpieczeństwa wśród obywateli, szczególnie w świetle aktualnych wydarzeń na świecie.
\end{abstract}

Słowa kluczowe: broń palna, pozwolenie na broń palną, reglamentacja dostępu do broni palnej

\section{UWAGI WPROWADZAJĄCE}

Zagadnienie dostępu do broni palnej, czy w świetle aktualnych wydarzeń społeczno-politycznych w Europie - raczej problem ograniczania dostępu do broni palnej — znajduje zarówno prawne, jak i ekonomiczne uzasadnienie do badań w ramach praktycznego podejścia do bezpieczeństwa jednostki w państwie i teoretycznych rozważań dotyczących stosunków obywatel-państwo ${ }^{1}$. Model zapro-

1 Rozważania w niniejszym opracowaniu będą prowadzone w kontekście sytuacji prawnej jednostki, z pominięciem tej sfery uregulowań prawnych, która dotyczy instytucjonalnego zakresu problematyki, związanego z posiadaniem broni palnej przez służby, inspekcje i straże oraz inne podmioty o charakterze zorganizowanego bytu prawnego. Prawna sfera dostępu do broni palnej dotyczy zarówno jednostki (obywatela) postawionej w sytuacji prawnej związanej w szczególności z zapewnieniem sobie samej bezpieczeństwa, czynności związanych z wykonywaniem pracy polegającej na zapewnieniu bezpieczeństwa innych osób i mienia czy sytuacji prawnej związanej z wykonywaniem polowań i czynnym uprawianiem sportu (strzelectwo sportowe), jak i uregulowań prawnych nadających prawo posiadania i używania broni palnej służbom inspekcjom i strażom. 
ponowany przez polskiego ustawodawcę w zasadniczo odbiega od europejskich i światowych rozwiązań, które angażują możliwości jednostki do samostanowienia o swoich potrzebach, a co za tym idzie - do zapewnienia sobie własnymi siłami poczucia bezpieczeństwa, dopuszczających znaczny katalog zachowań związanych z szerszym lub węższym prawem do posiadania broni palnej. W polskiej tradycji ustawodawczej nie ma i nigdy nie było gwarancji prawnych związanych z możliwością posiadania broni palnej, czy to na poziomie podstawowych praw i wolności gwarantowanych w ustawie zasadniczej, czy też w aktach niższej rangi. Należy zauważyć, że także orzecznictwo modelowało zawsze system wartości, takich jak bezpieczeństwo, własność i wolność, bez możliwości zabezpieczenia ich przez jednostkę z wykorzystaniem broni palnej.

W tym miejscu nasuwa się pytanie, czy jednostka ma prawo poprzez czynne działanie zabezpieczać swoje podstawowe wartości samodzielnie, czy jest skazana na łaskę opiekuńczych form działania państwa²? Tam, gdzie jednostka nie jest $\mathrm{w}$ stanie poradzić sobie samodzielnie, z pomocą może, a nawet powinno przyjść państwo. Jest to jedna $z$ naczelnych zasad określających prawny sens funkcjonowania państwa - zasada subsydiarności, przez wielu identyfikowana jako zasada pomocniczości. Należy z całą stanowczością podkreślić, że zasada pomocniczości opiera się na założeniu, że zadania, które mogą być realizowane przez jednostkę, nie powinny być realizowane przez państwo. Podobnie zasada ta odnosi się do różnych szczebli funkcjonalnego zorganizowania państwa regułą związaną z wyraźnym i jednoznacznym podziałem zadań jest, że organy niższego rzędu mogą być wyręczone przez organy nadrzędne, tylko jeśli nie są w stanie same wywiązywać się ze swoich obowiązków. Z jednej strony naturalne wydaje się, że aparat państwa ${ }^{3}$ nie może zastępować działań konkretnej jednostki, z drugiej jednak nie powinien być obojętny na sytuację, w której obywatel nie jest w stanie samodzielnie zrealizować określonych zadań. Należy pamiętać, że

${ }^{2}$ Skoro obywatel stawiany jest w sytuacji administrowanego, to w pewien sposób obdarza państwo kredytem zaufania, że w państwie prawa wszystkie działania podejmowane przez upoważnione i kompetentne organy mają na celu przyczynienie się do osiągnięcia czy utrzymania tych wartości, które są dla jednostki najistotniejsze. Wydaje się, że w płaszczyźnie skuteczności działań organów administrujących prawne reguły funkcjonowania administracji powinny być konsekwencją zasady subsydiarności, a więc tam, gdzie obywatel nie jest w stanie sam poradzić sobie z ochroną tych wartości, które są dla niego najistotniejsze, może wkroczyć aparat państwa. Zob. R. Mikowski, Antywartości w prawie administracyjnym jako efekt uprawnień dyskrecjonalnych Policji $w$ zakresie dostępu do broni palnej, [w:] Antywartości w prawie administracyjnym, red. A. Błaś, VI KrakowskoWrocławskie Spotkanie Naukowe Administratywistów, Warszawa 2016, s. 230.

3 Obowiązkiem władz publicznych jest zapewnienie bezpieczeństwa także poprzez działania polegające na wprowadzaniu ograniczeń w korzystaniu z praw i wolności.. Zob. Ł. Mikowski, Organy ochrony środowiska w systemie bezpieczeństwa spleczności lokalnych, [w:] Organ administracji publicznej w systemie bezpieczeństwa społeczności lokalnych, red. J. Boć, Ł. Mikowski, Wałbrzych 2016, s. 90 . 
pomoc ma polegać na wspieraniu, a nie na wyręczaniu. Założeniem ustrojodawcy nie było ingerowanie w sprawy, z którymi obywatele powinni sobie poradzić w sposób ich zdaniem zadowalający, a wyłącznie wspieranie tam, gdzie pomoc jest niezbędna ${ }^{4}$.

Niewątpliwie zasada proporcjonalności zawiera w sobie odniesienie do konieczności ograniczeń. Sięgnięcie po takie środki musi być uzasadnione koniecznością ochrony wartości ponadpodstawowych czy ponadjednostkowych. Musi istnieć swoisty normatywny imperatyw, który nakazuje skorzystać z takiej możliwości, której przesłanka w demokratycznym państwie została określona następująco:

Przesłanka konieczności ograniczenia w demokratycznym państwie, sformułowana w art. 31 ust. 3, stanowi w pewnym sensie odpowiednik wypowiadanych w orzecznictwie Trybunału postulatów kształtujących treść zasady proporcjonalności. Z jednej strony stawia ona każdorazowo przed prawodawcą wymóg stwierdzenia rzeczywistej potrzeby dokonania $\mathrm{w}$ danym stanie faktycznym ingerencji w zakres prawa bądź wolności jednostki. Z drugiej strony zaś winna ona być rozumiana jako wymóg stosowania takich środków prawnych, które będą skuteczne, a więc rzeczywiście służące realizacji zamierzonych przez prawodawcę celów ${ }^{5}$.

Tak więc w kontekście zasady proporcjonalności zawsze ważne jest pytanie o cel, któremu ma służyć takie ograniczenie. Czy zamierzony przez ustawodawcę cel jest możliwy do osiągnięcia bez naruszenia podstawowych standardów prawnych wyrażających istotę praw, których dotyczy ${ }^{6}$. Cel i środki służące do jego realizacji nie powinny prowadzić do naruszenia istoty prawa, a należy podkreślić także, że z zasadą proporcjonalności wiąże się wymóg stosowania takich środków prawnych, które będą skuteczne ${ }^{7}$. Środki te, jako niezbędne, „chronić będą określone wartości w sposób, bądź w stopniu, który nie mógłby być osiągnięty przy zastosowaniu innych środków. Niezbędność to również skorzystanie ze środków jak najmniej uciążliwych dla podmiotów, których prawa lub wolności ulegną ograniczeniu"s.

4 Zob. więcej m.in. J. Boć, Konstytucje Rzeczypospolitej oraz komentarz do Konstytucji RP z 1997 roku, red. J. Boć, Wrocław 1998, s. 16; D. Kijowski, Zasada adekwatności w prawie administracyjnym, „Państwo i Prawo” 1990, z. 4, s. 61; Z. Kmieciak, Ogólne zasady prawa i postępowania administracyjnego, Warszawa 2000, s. 111; M. Zdyb, J. Stelmasiak, J. Szreniawski, Zasada proporcjonalności w świetle konstytucji RP, [w:] Podmioty administracji publicznej i prawne formy ich działania. Studia i materiaty z konferencji jubileuszowej Profesora Eugeniusza Ochendowskiego, Toruń, 15-16 listopada 2005 roku, s. 471.

5 Uzasadnienie wyroku Trybunału Konstytucyjnego z dnia 12 stycznia 1999 roku w sprawie P $2 / 98$.

${ }^{6}$ P.J. Suwaj, Gwarancje bezstronności organów administracji publicznej w postępowaniu administracyjnym, Wrocław 2004, s. 57.

7 M. Zdyb, J. Stelmasiak, J. Szreniawski, op. cit., s. 477, 478.

8 Wyrok Trybunału Konstytucyjnego z dnia 12 stycznia 1999 roku w sprawie P 2/98.

Przegląd Prawa i Administracji 115, 2018

(C) for this edition by CNS 


\section{PODSTAWY PRAWNE ADMINISTROWANIA DOSTĘPEM DO BRONI PALNEJ}

Racjonalny ustawodawca nie widzi potrzeby, by wprowadzać mniej lub bardziej swobodny dostęp do broni palnej. Cały obrót bronią palną i dostęp do broni palnej jest restrykcyjnie reglamentowany ${ }^{9}$, ponieważ ustawodawca wychodzi z założenia, że to państwo ma monopol na zapewnienie bezpieczeństwa obywatelom ${ }^{10}$. Mając na uwadze poczynione rozważania, należy zauważyć, że ustawodawca nie wprowadził do Konstytucji Rzeczypospolitej Polskiej z dnia 2 kwietnia 1997 roku $^{11}$ żadnych zapisów, o których można powiedzieć, że w najmniejszym stopniu są związane z prawem posiadania broni palnej przez obywatela ${ }^{12}$. Z analizy Konstytucji RP można wyprowadzić wniosek, że ograniczenia w przedmiotowym zakresie stanowią niekwestionowaną zasadę, od której w wyjątkowych przypadkach ${ }^{13}$ przewidziane zostały nieliczne odstępstwa. Potwierdzenie tej tezy można bez trudu odnaleźć w art. 2 ustawy z dnia 21 maja 1999 roku o broni i amu-

9 Użycie w tym przedmiocie określenia ,reglamentacja” wydaje się uprawnione o tyle, o ile „ujęcie to dosyć wyraźnie ustala przedmiotowy zasięg reglamentacji, kojarzy terminologię ekonomiczną i prawniczą, uzyskuje uniwersalne znaczenie, nie warunkowane charakterem podmiotu gospodarującego". J. Boć, [w:] A. Błaś, J. Boć, J. Jeżewski, Nauka administracji, Wrocław 2013, s. 231. W każdym innym pojmowaniu zjawiska prawnego ograniczania dostępu do broni palnej zdecydowanie trafniejsze będzie wskazanie na funkcję porządkową administracji publicznej, ukrytą pod pojęciem policji administracyjnej. Ta zaś rozumiana jako działania polegające na ochronie życia, zdrowia, bezpieczeństwa obywateli, porządku publicznego czy ładu przestrzennego wpisuje się wraz z reglamentacją w sferę ingerencji administracji publicznej. Jak by nie konstatować działalności administracji publicznej, nie uciekniemy od wrażenia, że dotyk jej możliwości subsydiarnych będzie zawsze postrzegany jako ingerencja w różne sfery życia społecznego (sferę praw i wolności obywatelskich), co w przedmiotowym temacie uwypukla się szczególnie. Zob. także J. Boć, Prawniczy stownik wyrazów trudnych, Wrocław 2005, s. 314-315.

10 Ustawodawca, wychodząc z takiego założenia, postrzega w takim modelu zwiększenie bezpieczeństwa, czy takowych odczuć obywateli, które powinny polegać na utwierdzeniu jednostki w przekonaniu, że obecność broni palnej w życiu codziennym jest ograniczona do niezbędnego minimum. Niezbędność ta jest związana z posiadaniem broni palnej przez uprawnione do tego podmioty (służby, inspekcje i straże), które są odpowiedzialne za zapewnienie bezpieczeństwa jednostce (w tym także poczucia bezpieczeństwa). R. Mikowski, op. cit., s. 231-232.

11 Dz.U. Nr 78, poz. 483 ze zm.

12 Tego typu systemowe założenia skierowane zostały zarówno do ludzkiej (płaszczyzna naturalna), jak i instytucjonalnej (płaszczyzna konwencji państwowej) sfery regulacji prawnej. Analiza treści art. 20 Konstytucji RP uprawnia do stwierdzenia istnienia zasady polegającej raczej na kreowaniu i ochronie w sferze wolności gospodarczej niż na wolności gospodarczej odzwierciedlającej stan realny. R. Sowiński, Wolność i ustawowa swoboda działalności gospodarczej, Wrocław 2007, s. 182.

13 Sytuacje te zostały ściśle określone w aktach normatywnych rangi ustawy oraz w aktach wykonawczych do tych ustaw. Należy podkreślić, że także akty normatywne administracji innej rangi niż już wymienione potwierdzają, że posiadanie, używanie, noszenie, nabywanie czy w końcu zbywanie broni palnej jest zjawiskiem wyjątkowym, a analiza praktyki w tym zakresie utwierdza w przekonaniu, że wręcz incydentalnym. 
nicji14, w którym jednoznacznie zostało wyartykułowane ograniczenie wskazujące, że poza przypadkami określonymi w ustawie nabywanie, posiadanie oraz zbywanie broni i amunicji jest zabronione. Przepis, określając zakres przedmiotowy i podmiotowy, reguluje zasady dotyczące postępowania $z$ bronią palną i amunicją przez wszystkie osoby, którym prawo przyznaje możliwości nabywania, przechowywania, przewozu, zbywania i deponowania broni i amunicji. Zakres podmiotowy ${ }^{15}$ ustawy dotyczy zarówno obywateli polskich, jak i cudzoziemców ${ }^{16}$, co jednoznacznie zostało stwierdzone w art. 1 ustawy o broni i amunicji. Analiza ustawy o broni i amunicji potwierdza, że już w obrębie samej regulacji wiele czynności z bronią palną lub w stosunku do broni palnej podejmuje się w sytuacjach wyjątkowych lub jest w ogóle zabronionych ${ }^{17}$.

Wśród regulacji prawnych na poziomie ustawowym dotyczących ograniczeń związanych z administrowaniem dostępem do broni palnej należy wymienić także ustawę z dnia 22 sierpnia 1997 roku o ochronie osób i mienia ${ }^{18}$, która dopuszcza posiadanie i używanie broni palnej przez osoby wykonujące czynności zawodowe w rozumieniu ustawy z dnia 26 czerwca 1974 roku - Kodeks pracy ${ }^{19}$. Jako wyjątek od zasady ograniczającej dostęp do broni palnej należy potraktować także zapisy ustawy z dnia 21 czerwca 2002 roku o materiałach wybuchowych przeznaczonych do użytku cywilnego ${ }^{20}$ czy w końcu ustawę z dnia 22 czerwca 2001 roku o wykonywaniu działalności gospodarczej w zakresie wytwarzania i obrotu materiałami wybuchowymi, bronią, amunicją oraz wyrobami i technologią o przeznaczeniu wojskowym lub policyjnym ${ }^{21}$.

Podstaw prawnych związanych z ograniczeniem dostępu do broni palnej należy szukać także w aktach wykonawczych, wśród których szczególne miejsce zajmuje rozporządzenie Ministra Spraw Wewnętrznych z dnia 26 sierpnia 2014 ro$\mathrm{ku} \mathrm{w}$ sprawie przechowywania, noszenia oraz ewidencjonowania broni i amuni$\mathrm{cji}^{22}$, które w najpełniejszym stopniu uzupełnia w przedmiotowym zakresie postanowienia ustawy o broni i amunicji. Już z pobieżnej analizy tego aktu można wyprowadzić wniosek, że uzyskanie pozwolenia na broń palną jest tylko począt-

14 Dz.U. z 2017 r. poz. 1839.

15 Z zakresu podmiotowego komentowanej ustawy wyłączone zostały służby, inspekcje i straże, co znalazło wyraz w art. 3 ustawy. Uzasadnia to zamierzone podejście autora niniejszego artykułu do zakresu opracowania, co podniesione zostało na wstępie.

16 Zob. B. Kowalczyk, R. Mikowski, Administracyjnoprawna sytuacja cudzoziemca w Polsce, [w:] Prawo administracyjne, red. J. Boć, Wrocław 2010, s. 510-526.

17 Zob. w szczególności art. 4 ust. 5 pkt 1 i 2, art. 6 ust. 1, art. 6a ust. 1, art. 7a, art. 9 ust. 1, art. 10 ust. 1 , art. 10 b ust. 1 , art. 13 ust. 1 , art. 14 , art. 15 , art. 17 ust. 1 , art. 18 . ust. $1 \mathrm{n}$.

18 Dz.U. z 2016 r. poz. 1432 ze zm.

19 Dz.U. z 2016 r. poz. 1666 ze zm.

20 Dz.U. z 2017 r. poz. 283 ze zm.

21 Dz.U. z 2017 r. poz. 290 ze zm.

22 Dz.U. z 2014 r. poz. 1224. 
kiem drogi do spełnienia wszystkich prawnych ${ }^{23}$ wymogów legalnego posiadania i używania broni palnej w Polsce. Zgodnie z $§ 2$ analizowanego rozporządzenia broń i amunicję przechowuje się w odpowiednio przystosowanym do tego celu pomieszczeniu, zwanym dalej magazynem broni, lub w urządzeniach spełniających wymagania co najmniej klasy S124 według normy PN-EN 14450. Interesująco uregulowana została kwestia noszenia broni palnej, o której traktuje $\S 8$ ust. 1-4 komentowanego rozporządzenia, w myśl którego broń palną nosi się w kaburach lub futerałach w taki sposób, by była jak najmniej widoczna dla otoczenia. Dotyczy to zarówno broni palnej przeznaczonej do celów ochrony osobistejej ${ }^{25}$, jak i broni palnej do celów sportowych ${ }^{26}$ czy łowieckich ${ }^{27}$. Ciekawostką wskazującą zgoła odmienne podejście do problemu przenoszenia broni palnej i związany $\mathrm{z}$ tym fakt subiektywnego odczuwania bezpieczeństwa wydają się uregulowania tej kwestii w Szwajcarii. Tam regulacje prawne nakazują przenoszenie (transportowanie) broni palnej w środkach komunikacji publicznej w sposób jawny, to jest tak, by wszyscy pasażerowie mogli dostrzec, że dana osoba posiada przy sobie broń, z którą jedzie na przykład na strzelnicę sportową. Czy zatem jest bezpiecznie

23 Osobnym, choć niezmiernie ciekawym zagadnieniem są ekonomiczne czy finansowe instrumenty ograniczania dostępu do broni palnej, a związane chociażby z samymi kosztami wydania pozwolenia na broń, w tym kosztami badań lekarskich czy wydania decyzji administracyjnej. Do sygnalizowanych ograniczeń można zaliczyć także koszt zakupu broni, koszt zakupu specjalnych szaf czy sejfów spełniających wymagania normy S1, a służących do prawidłowego przechowywania broni czy innych kosztów obejmujących szkolenia, korzystanie ze strzelnic sportowych lub polowań.

${ }^{24}$ Co ciekawe, w środowisku osób posiadających pozwolenie na broń zgodnie wyrażane są opinie, że podnoszenie klasy zabezpieczeń dla szaf czy sejfów do przechowywania broni, które znajdują się w domach czy mieszkaniach prywatnych, niekoniecznie musi zwiększać bezpieczeństwo przechowywanej broni. Należałoby się zastanowić, w jakim celu, a raczej przed kim chronimy broń palną, czy raczej komu i jak należy utrudnić dostęp do broni. Osobą nieuprawnioną jest zarówno domownik (mąż, żona, matka, dziecko nieposiadający pozwolenia na broń), jak i włamywacz, który przychodzi celowo po naszą broń. O ile domownikowi uniemożliwimy wejście w posiadanie broni poprzez porządne zamknięcie szafy z bronią (chociażby na zwykłą kłódkę czy zamek — a najlepiej na zamek szyfrowy, ponieważ nie ma wtedy wątpliwości, gdzie znajduje się klucz i w czyim jest aktualnie posiadaniu), o tyle włamywaczowi co najwyżej utrudnimy sforsowanie zabezpieczeń. Jak powszechnie wiadomo, złamanie każdych zabezpieczeń jest tylko kwestią czasu. Wydaje się, że skoro włamywacz poradził sobie (pod nieobecność właściciela) z zabezpieczeniami mieszkania czy domu, to klasa zabezpieczeń S1 szafy na broń nie sprawi mu żadnego kłopotu. Bezpieczeństwo przechowywania broni palnej w domu powinno wykluczyć przypadkowe wejście w posiadanie tej broni przez domownika, szczególnie przez dzieci, ponieważ taka sytuacja wydaje się szczególnie niebezpieczna.

25 Ta przenoszona jest w kaburach przylegających do ciała, pod okryciem wierzchnim.

26 Ta przenoszona jest w odpowiednio do tego przeznaczonych futerałach, walizkach, torbach.

$27 \mathrm{~W}$ tym miejscu chodzi o przemieszczanie broni np. w środkach komunikacji miejskiej czy w miejscach publicznych, a nie w trakcie polowań. Zgodnie bowiem z $\S 8$ ust. 4 broń palną przeznaczoną do celów łowieckich w obwodach łowieckich nosi się w czasie polowania w sposób określony w przepisach wydanych na podstawie art. 43 ust. 3 ustawy z dnia 13 października 1995 roku — Prawo łowieckie (Dz.U. z 2013 r. poz. 1226 ze zm.).

Przegląd Prawa i Administracji 115, 2018

(C) for this edition by CNS 
wtedy, gdy nie widzimy zagrożenia, czy może wtedy, gdy państwo deklaruje nasze bezpieczeństwo ${ }^{28}$ ?

Istotne regulacje z punktu widzenia ograniczania dostępu do broni palnej, na poziomie aktów wykonawczych, zawiera również rozporządzenie Ministra Spraw Wewnętrznych i Administracji z dnia 20 marca 2000 roku w sprawie egzaminu ze znajomości przepisów dotyczących posiadania broni oraz umiejętności posługiwania się bronią ${ }^{29}$. Rozporządzenie określa tryb przeprowadzania egzaminu ze znajomości przepisów dotyczących posiadania i używania broni oraz umiejętności posługiwania się bronią, zakres przedmiotowy egzaminu, skład komisji egzaminacyjnej i stawki ${ }^{30}$ odpłatności za egzamin. Zgodnie z $§ 3$ komentowanego rozporządzenia egzamin składa się z części teoretycznej i praktycznej. Zakres przedmiotowy teoretycznej części egzaminu obejmuje sprawdzenie znajomości przepisów ustawy o broni i amunicji oraz przepisów wydanych na jej podstawie, a także znajomości przepisów ustawy z dnia 6 czerwca 1997 roku — Kodeks kar$n y^{31}$ dotyczących przestępstw związanych z bronią.

Część praktyczna egzaminu obejmuje sprawdzenie przestrzegania szczegółowych zasad zachowania bezpieczeństwa na strzelnicy, umiejętności prawidłowego rozkładania i składania, ładowania i rozładowywania danej broni, postępowania z bronią niesprawną w stopniu uniemożliwiającym dalsze strzelanie, określenia części broni oraz przeprowadzenie sprawdzianu strzeleckiego z użycia danego rodzaju broni.

Ustawodawca przewidując nabycie broni palnej na odległość, dopuszcza możliwość przesyłania broni i amunicji za pośrednictwem operatorów świadczących usługi pocztowe. Szczegółowe zasady w tym zakresie zostały określone w rozporządzeniu Ministra Spraw Wewnętrznych z dnia 24 sierpnia 2012 roku w sprawie szczegółowego trybu i warunków przesyłania broni lub amunicji za pośrednictwem operatorów świadczących usługi pocztowe ${ }^{32}$. Ograniczenia w tym zakresie polegają na wyłączeniu dowolności zarówno sposobu przesyłania broni palnej i amunicji, jak i podmiotów mogących świadczyć tego typu usługi. Warto chociażby nadmienić, że broń przesyła się w opakowaniu zaplombowanym i oznakowanym ${ }^{33}$ przez operatora w sposób trwały i widoczny. Jeżeli podczas przesyłania paczki zaistnieje konieczność jej przechowania, do czasu wydania

28 Zob. Administracja publiczna. Ustrój administracji państwowej centralnej. Komentarz, red. B. Szmulik, K. Miaskowska-Daszkiewicz, Warszawa 2012.

29 Dz.U. z 2017 r. poz. 1756.

30 Jak już wcześniej sygnalizowano, ograniczenia finansowe stanowią także sporą barierę w dostępie do broni palnej, co widać szczególnie w tym miejscu. Kwoty związane z właściwym egzaminem wahają się od 500 do $1150 \mathrm{zł}$.

31 Dz.U. z 2016 r. poz. 1137 ze zm.

32 Dz.U. z 2012 r. poz. 1004.

$33 \mathrm{Na}$ opakowaniu przesyłki umieszcza się pouczenie: „Znalazca niniejszej przesyłki powinien niezwłocznie przekazać ją najbliższej jednostce Policji. Przesyłki nie rozplombowywać i nie otwierać". 
przesyłki adresatowi przechowuje się ją w magazynie broni. Operator podczas przewożenia przesyłki zapewnia bezpośrednią ochronę fizyczną przesyłki przez pracownika ochrony uzbrojonego w broń palną bojową. Dodatkowo przewożenie przesyłek wykonuje się przy użyciu pojazdów spełniających wymagania dla pojazdów przewożących wartości pieniężne oraz pojazdów ubezpieczających.

Nie w każdych warunkach można swobodnie rozporządzać nabytą wcześniej (legalnie) bronią palną. Odpowiednią w tym zakresie regulacją są postanowienia rozporządzenia Ministra Spraw Wewnętrznych i Administracji z dnia 9 czerwca 2004 roku w sprawie szczegółowych zasad deponowania i niszczenia broni i amunicji w depozycie Policji, Żandarmerii Wojskowej lub organu celnego oraz stawki odpłatności za ich przechowywanie w depozycie ${ }^{34}$. W sytuacjach określonych przez ustawodawcę ${ }^{35}$ broń i amunicja, zgodnie z $\S 1$ rozporządzenia, są deponowane w jednostce organizacyjnej Policji, Żandarmerii Wojskowej właściwej w sprawach wydawania pozwoleń na broń lub jednostce organizacyjnej urzędu celnego właściwej do przyjęcia broni do depozytu. Warto w tym miejscu zauważyć, że kolejną niedogodnością czy uciążliwością dla posiadacza broni jest konieczność opłacenia depozytu w sytuacji, gdy już broń do niego musi trafić. Zgodnie z $§ 11$ ust. 1 za przechowywanie broni oraz amunicji w depozycie jest pobierana opłata w wysokości $1 \%$ opłaty za wydanie pozwolenia na broń ${ }^{36}$ osobie fizycznej za każdą dobę przechowywania, a jest ona pobierana od każdej sztuki broni przyjętej do depozytu.

Na koniec powinny zostać przedstawione możliwości wprowadzenia ograniczeń związanych z noszeniem legalnie posiadanej broni palnej, które mogą zostać zawarte $\mathrm{w}$ regulacjach rozporządzeniowych. Tego typu ograniczenia uprawnienia do posiadania broni palnej na podstawie uprzednio wydanej ostatecznej decyzji administracyjnej, jaką jest pozwolenie na broń, zostało zawarte między innymi w rozporządzeniu Ministra Spraw Wewnętrznych i Administracji z dnia 28 czerwca 2017 roku w sprawie wprowadzenia czasowego zakazu noszenia broni i przemieszczania jej w stanie rozładowanym ${ }^{37}$. Wprowadzono wówczas zakaz noszenia i przemieszczania w stanie rozładowanym wszelkiego rodzaju broni na obszarze województwa małopolskiego w okresie od dnia 1 lipca do 13 lipca 2017 roku,

34 Dz.U. Nr 152, poz. 1609.

35 Do takich należy zaliczyć w szczególności utratę pozwolenia na broń, kiedy to osoba zobowiązana jest do zbycia broni palnej lub zdeponowania broni w sposób określony w komentowanym rozporządzeniu.

36 Opłata za wydanie pozwolenia na broń wynosi 242 zł i wynika bezpośrednio z ustawy z dnia 16 listopada 2006 roku o opłacie skarbowej (Dz.U. z 2016 r. poz. 1827 ze zm.).

37 Dz.U. poz. 1280. Tego typu ograniczeń można doszukać się znacznie więcej — zob. rozporządzenie Ministra Spraw Wewnętrznych i Administracji z dnia 20 maja 2016 roku w sprawie wprowadzenia czasowego zakazu noszenia broni i przemieszczania jej w stanie rozładowanym (Dz.U. poz. 715) rozporządzenie Ministra Spraw Wewnętrznych z dnia 5 stycznia 2015 roku w sprawie wprowadzenia czasowego zakazu noszenia oraz przemieszczania w stanie rozładowanym wszelkiego rodzaju broni (Dz.U. poz. 94) czy adekwatne regulacje z 2010, 2009 i 2008 roku. 
a na obszarze miasta stołecznego Warszawy w okresie od 5 do7 lipca 2017 roku czy na obszarze województwa dolnośląskiego w okresie od 18 do 31 lipca 2017 roku. Tego typu zakazy są wprowadzane w sytuacjach zwiększonego zagrożenia dla bezpieczeństwa publicznego ze względu na organizowane na danym obszarze imprezy okolicznościowe, sportowe czy przyjazd VIP-ów. Tak więc w podanych przypadkach przyczyną wprowadzenia zakazów było odpowiednio organizacja 41. Sesji Komitetu Światowego Dziedzictwa UNESCO w Krakowie, wizyta prezydenta Donalda Trumpa czy zawody The World Games 2017 organizowane we Wrocławiu.

\section{WNIOSKI}

Polski ustawodawca nie gwarantuje obywatelowi dostępu do posiadania broni palnej ${ }^{38}$, a poprzez liczne regulacje zajmujące różne miejsce $\mathrm{w}$ hierarchii źródeł prawa $^{39}$ pokazuje, że ograniczenia $\mathrm{w}$ tym zakresie stanowią daleko idącą sferę reglamentacji adminstracyjnoprawnej. W związku z aktualną sytuacją społeczno-polityczną oraz wydarzeniami mającymi miejsce zarówno w kraju, jak i w Unii Europejskiej $^{40}$ należy szczególnie pochylić się nad problemem dostępu do broni palnej. Przede wszystkim aktualne i racjonalne wydaje się podejście ustawodawcy, który na każdym kroku w obowiązującym prawodawstwie podkreśla, że subiektywne odczucia obywatela, związane z zapewnieniem sobie samemu bezpieczeństwa przy wykorzystaniu broni palnej, nie znajdują w dzisiejszych realiach uzasadnienia. Dodatkowo subiektywnie odczuwana potrzeba posiadania broni palnej przez osoby, które nie prezentują odpowiednich postaw dających zgodnie $\mathrm{z}$ art. 10 ust. 1 ustawy o broni i amunicji gwarancję bezpieczeństwa ${ }^{41}$, może prowadzić do sytuacji niebezpiecznych. Ważne jest przy tym, by organy administracji

38 Nawet prawidłowa realizacja zasady subsydiarności (pomocniczości) na gruncie prawa krajowego nie ma w świetle konstytucji charakteru prawa podmiotowego w zakresie posiadania broni palnej. Zamknięcie systemu źródeł prawa w Konstytucji RP nie przyczyniło się do zawężenia katalogu wszystkich wątpliwości dotyczących stanowienia prawa przez organy administracji publicznej. Zob. M. Stahl, Formy prawne w sferze działań zewnętrznych administracji publicznej, [w:] R. Hauser, Z. Niewiadomski, A Wróbel, System Prawa Administracyjnego, t. 5. Prawne formy działania administracji, red. A. Błaś et al., Warszawa 2013, s. 230.

39 Zob. np. w związku z zasadą korzystania z wolności i praw przez każdego, kto znajdzie się pod władzą Rzeczypospolitej Polskiej. Z. Leoński, Zarys prawa administracyjnego, Warszawa 2004, s. 43.

40 Także na świecie — zob. rosnąca liczba doniesień (także, a może przede wszystkim medialnych) o nieuprawnionym, nielegalnym czy wręcz przestępczym użyciu broni palnej.

41 Przesłanki konieczne, które muszą być spełnione łącznie, by uzyskać pozwolenie na broń, to wymogi postawione przede wszystkim w sferze osobowej wnioskodawcy. Osoba taka nie może stanowić zagrożenia dla samego siebie, porządku lub bezpieczeństwa publicznego oraz musi przedstawić ważną przyczynę posiadania broni.

Przegląd Prawa i Administracji 115, 2018

(C) for this edition by CNS 
odpowiedzialne za konkretyzację norm reglamentacyjnych ${ }^{42}$ dotyczących dostępu do broni palnej nie interpretowały rozszerzająco tych norm, szczególnie w kontekście językowym ${ }^{43}$. Trzeba mieć tu na uwadze takie działania organów państwa, które znajdując uzasadnienie w konstrukcji uznania administracyjnego, będą się przyczyniać lub powodować osiąganie celów całkowicie przeciwnych do wartości zaplanowanych przez ustawodawcę. Możliwość legalnego posiadania broni palnej jest wyjątkiem od zasady reglamentacji dostępu do broni. „Trzeba zwrócić uwagę na to, iż narzucenie woli państwa w ramach reglamentacji odbywa się zawsze na podstawie szczegółowych podstaw prawnych, ma znaczenie konkretne oraz nie jest związane z jednym sposobem powstawania sytuacji prawnych"44.

\section{BIBLIOGRAFIA}

Administracja publiczna. Ustrój administracji państwowej centralnej. Komentarz, red. B. Szmulik, K. Miaskowska-Daszkiewicz, Warszawa 2012.

Administracja publiczna. Zagadnienia prawne i koncepcje zarządzania, red. P. Borszowski, B. Detyna, Wałbrzych 2014.

Administracja publiczna pod rzadami prawa. Księga pamiatkowa z okazji 70-lecia urodzin prof. zw. dra hab. Adama Błasia, red. J. Korczak, Wrocław 2016.

Boć J., [w:] A. Błaś, J. Boć, J. Jeżewski, Nauka administracji, Wrocław 2013.

Boć J., Konstytucje Rzeczypospolitej oraz komentarz do Konstytucji RP z 1997 roku, red. J. Boć, Wrocław 1998.

Boć J., Prawniczy słownik wyrazów trudnych, Wrocław 2005.

Gromski W., Zagadnienia granic instrumentalizacji prawa, [w:] Z zagadnień teorii i filozofii prawa. Instrumentalizacja prawa, red. A. Kozak, Wrocław 2000.

Kiczka K., Krajowy organ administracji publicznej w prawie unijnym, Wrocław 2013.

Kijowski D., Zasada adekwatności w prawie administracyjnym, „Państwo i Prawo” 1990, z. 4.

Kmieciak Z., Ogólne zasady prawa i postępowania administracyjnego, Warszawa 2000.

Kocowski T., Reglamentacja gospodarcza, [w:] A. Borkowski, A. Chełmoński, M. Guziński, K. Kiczka, L. Kieres, T. Kocowski, M. Szydło, Administracyjne prawo gospodarcze, Wrocław 2009.

Kowalczyk B., Mikowski R., Administracyjnoprawna sytuacja cudzoziemca w Polsce, [w:] Prawo administracyjne, red. J. Boć, Wrocław 2010.

Leoński Z., Zarys prawa administracyjnego, Warszawa 2004.

Lisowski P., Regulacje strukturalne w polskim samorzadzie terytorialnym, Wrocław 2013.

Mikowski Ł., Organy ochrony środowiska w systemie bezpieczeństwa spłeczności lokalnych, [w:] Organ administracji publicznej w systemie bezpieczeństwa społeczności lokalnych, red. J. Boć, Ł. Mikowski, Wałbrzych 2016.

42 T. Kocowski, Reglamentacja gospodarcza, [w:] A. Borkowski et al., Administracyjne prawo gospodarcze, Wrocław 2009, s. 478.

43 „Sam instrumentalny charakter prawa choć niewątpliwie jest warunkiem koniecznym, to jednak nie może być uznany za warunek wystarczający do rzeczywistego wykorzystania prawa jako środka osiągania założonych celów”. W. Gromski, Zagadnienia granic instrumentalizacji prawa, [w:] Z zagadnień teorii i filozofii prawa. Instrumentalizacja prawa, red. A. Kozak, Wrocław 2000, s. 89.

44 Prawo administracyjne, red. J. Boć, Wrocław 2010, s. 360. 
Mikowski R., Antywartości w prawie administracyjnym jako efekt uprawnień dyskrecjonalnych Policji $w$ zakresie dostęu do broni palnej, [w:] Antywartości w prawie administracyjnym, red. A. Błaś, VI Krakowsko-Wrocławskie Spotkanie Naukowe Administratywistów, Warszawa 2016.

Postępowanie administracyjne - ogólne, podatkowe, egzekucyjne i przed sądami administracyjny$m i$, red. M. Wierzbowski, M. Szubiakowski, A. Wiktorowska, wyd. 18, Warszawa 2017.

Prawo administracyjne, red. J. Boć, Wrocław 2010.

Sowiński R., Wolność i ustawowa swoboda działalności gospodarczej, Wrocław 2007.

Stahl M., Formy prawne w sferze działań zewnętrznych administracji publicznej, [w:] R. Hauser, Z. Niewiadomski, A Wróbel, System Prawa Administracyjnego, t. 5. Prawne formy działania administracji, red. A. Błaś, J. Boć, M. Stahl, K. Ziemski, Warszawa 2013.

Stan i kierunki rozwoju nauk administracyjnych, red. A. Błaś, J. Boć, Wrocław 2014.

Suwaj P.J., Gwarancje bezstronności organów administracji publicznej w postępowaniu administracyjnym, Wrocław 2004.

Szydło M., Krajowy parlament jako regulator sektorów sieciowych, Warszawa 2013.

Uzasadnienie wyroku Trybunału Konstytucyjnego z dnia 12 stycznia 1999 roku w sprawie P 2/98. Wyrok Trybunału Konstytucyjnego z dnia 12 stycznia 1999 roku w sprawie P 2/98.

Zdyb M., Stelmasiak J., Szreniawski J., Zasada proporcjonalności w świetle konstytucji RP, [w:] Podmioty administracji publicznej i prawne formy ich działania. Studia i materiały z konferencji jubileuszowej Profesora Eugeniusza Ochendowskiego, Torun, 15-16 listopada 2005 roku.

\section{AKTY PRAWNE}

Konstytucja Rzeczypospolitej Polskiej z dnia 2 kwietnia 1997 roku (Dz.U. Nr 78, poz. 483 ze zm.).

Rozporządzenie Ministra Spraw Wewnętrznych i Administracji z dnia 20 marca 2000 roku w sprawie egzaminu ze znajomości przepisów dotyczących posiadania broni oraz umiejętności posługiwania się bronią (Dz.U. z 2017 r. poz. 1756).

Rozporządzenie Ministra Spraw Wewnętrznych i Administracji z dnia 9 czerwca 2004 roku w sprawie szczegółowych zasad deponowania i niszczenia broni i amunicji w depozycie Policji, Żandarmerii Wojskowej lub organu celnego oraz stawki odpłatności za ich przechowywanie w depozycie (Dz.U. Nr 152, poz. 1609).

Rozporządzenie Ministra Spraw Wewnętrznych z dnia 24 sierpnia 2012 roku w sprawie szczegółowego trybu i warunków przesyłania broni lub amunicji za pośrednictwem operatorów świadczących usługi pocztowe (Dz.U. z 2012 r. poz. 1004).

Rozporządzenie Ministra Spraw Wewnętrznych z dnia 26 sierpnia 2014 roku w sprawie przechowywania, noszenia oraz ewidencjonowania broni i amunicji (Dz.U. z 2014 r. poz. 1224.).

Rozporządzenie Ministra Spraw Wewnętrznych z dnia 5 stycznia 2015 roku w sprawie wprowadzenia czasowego zakazu noszenia oraz przemieszczania w stanie rozładowanym wszelkiego rodzaju broni (Dz.U. poz. 94).

Rozporządzenie Ministra Spraw Wewnętrznych i Administracji z dnia 20 maja 2016 roku sprawie wprowadzenia czasowego zakazu noszenia broni i przemieszczania jej w stanie rozładowanym (Dz.U. poz. 715).

Rozporządzenie Ministra Spraw Wewnętrznych i Administracji z dnia 28 czerwca 2017 roku w sprawie wprowadzenia czasowego zakazu noszenia broni i przemieszczania jej w stanie rozładowanym (Dz.U. poz. 1280).

Ustawa z dnia 26 czerwca 1974 roku - Kodeks pracy (Dz.U. z 2016 r. poz. 1666 ze zm.).

Ustawa z dnia 13 października 1995 roku — Prawo łowieckie (Dz.U. z 2013 r. poz. 1226 ze zm.).

Ustawa z dnia 6 czerwca 1997 roku — Kodeks karny (Dz.U. z 2016 r. poz. 1137 ze zm.).

Ustawa z dnia 22 sierpnia 1997 roku o ochronie osób i mienia (Dz.U. z 2016 r. poz. 1432 ze zm.).

Ustawa z dnia 21 maja 1999 roku o broni i amunicji (Dz.U. z 2017 r. poz. 1839).

Przegląd Prawa i Administracji 115, 2018

(C) for this edition by $\mathrm{CNS}$ 
Ustawa z dnia 22 czerwca 2001 roku o wykonywaniu działalności gospodarczej w zakresie wytwarzania i obrotu materiałami wybuchowymi, bronią, amunicją oraz wyrobami i technologią o przeznaczeniu wojskowym lub policyjnym (Dz.U. z 2017 r. poz. 290 ze zm.).

Ustawa z dnia 21 czerwca 2002 roku o materiałach wybuchowych przeznaczonych do użytku cywilnego (Dz.U. z 2017 r. poz. 283 ze zm.).

Ustawa z dnia z dnia 16 listopada 2006 roku o opłacie skarbowej (Dz.U. z 2016 r. poz. 1827 ze zm.).

\section{A FEW REMARKS ON THE LEGAL GROUNDS FOR RESTRICTION OF ACCESS TO FIREARMS IN POLAND}

\section{Summary}

The paper outlines the legal grounds for access to firearms in Poland, taking into account the current trends related to the government's obligation to provide security to citizens. The article includes an analysis of both the constitutional principles and the applicable legislation in force, along with secondary legislation (Regulations), is aimed at the clarification of the importance of the restrictions being introduced by the legislature in this field. The preventive and conservative approach of the legislature towards the expectations of some circles of stakeholders justifies the statement that the admission of firearms to be marketed is a strictly regulated exception to the principle of restricting access to firearms, which significantly contributes to the increased sense of security among citizens, especially in the light of current developments in the world.

Keywords: firearms, firearms permit, firearms access regulation 